УАК 616.314.-163.4-089.818.1

(СН. В. Гасюк ${ }^{1}$, І. Ю. Попович ${ }^{2}$

$\triangle \mathrm{BHЗ} \mathrm{«Тернопільський} \mathrm{державний} \mathrm{медичний} \mathrm{університет} \mathrm{імені} \mathrm{I.} \mathrm{Я.} \mathrm{Горбачевського»}{ }^{1}$ ВАНЗ України «Українська медична стоматологічна академія», м. Полтава ${ }^{2}$

\title{
Оптимізація способів лікування ускладненого карієсу шляхом вибору методики препарування системи кореневих каналів
}

\begin{abstract}
Резюме. У статті приведено результати дослідження ефективності препарування кореневих каналів із застосуванням найбілыш розповсюджених у практичній роботі лікарів-стоматологів системи інструментів. За останні десятиріччя значно поліпшилась якість ендодонтичних втручань, яка пов'язана із появою нового інструментарію, технологій препарування кореневих каналів та їх обтурації. Питання вибору системи для препарування кореневих каналів залишається досить дискусійним. Отримані результати дають можливість рекомендувати для найефективнішого препарування кореневих каналів використовувати машинні фрайли «Mtwo» и «Pro taper».
\end{abstract}

Ключові слова: едодонт, препарування кореневих каналів, фрайли, шліфр зуба.

\section{Н. В. Гасюк ${ }^{1}$, И. Ю. Попович ${ }^{2}$}

ГВУЗ «Тернопольский государственный медицинский университет имени И. Я. Горбачевского» ${ }^{1}$

ВГУЗ Украины «Украинская медицинская стоматологическаяа академия», г. Полтава ${ }^{2}$

\section{Оптимизация способов лечения осложненного кариеса путем выбора методики препарирования системы корневых каналов}

\begin{abstract}
Резюме. В статье приведены результаты изучения качества эффективности препарирования корневых каналов из применением наиболее распрастроненных в практике врачей-стоматологов систем инструментов. На протяжении последних лет постоянно осуществляется усовершенствование эндодонтического лечения, которое связано с появленим нового инструментария, технологий препарирования корневых каналов и их обтурации. Вопрос выбора системы для препарирования корневых каналов остается довольно дискуссионным. Выходя из проведенных нами исследований и полученных результатов, для наиболее эффективного препарирования корневых каналов рекомендуем использование машинных файлов «Mtwo» и «Pro taper».
\end{abstract}

Ключевые слова: эндодонт, препарирование корневых каналов, файлы, шлиф зуба.

\section{N. V. Hasiuk ${ }^{1}$, I. Yu. Popovych ${ }^{2}$ \\ SHEI «Ternopil State Medical University by I. Ya. Horbachevsky»1 ${ }^{1}$ \\ HSEI of Ukraine «Ukrainian Medical Stomatological Academy», Poltava ${ }^{2}$ \\ Optimization of ways of treatment of complicated caries by the choice of methods of preparation of root canals}

Summary. This paper presents the results of research on effectiveness root canal preparation using the most common in practice dentists of tools. During last years endodontic treatment are improved with 
appearance new instruments and technologist of preparation root canals and their obturation. The choice of system for preparation root canal still to be discutable. Our own studies allow to draw the following comclusion. Used for preparation of root canal machine fails «Mtwo» and «Pro taper» are most effected.

Key words: endodont, preparation root canal, fails, tooth slice.

Вступ. Відсоток позитивних результатів лікування ускладненого карієсу з використанням традиційних методів (біологічний, хірургічний після девіталізації пульпи) дуже незначний і коливається від 30 до 70 \% випадків [1, 2].

Тому особливо гостро стоїть питання впровадження в практичну стоматологію нових ендодонтичних інструментів, медикаментів і технологій, що дадуть можливість підвищити ефективність лікування та запобігти ускладненням. Але активне впровадження в практику сучасних матеріалів і технологій ендодонтичного лікування потребує удосконалення традиційних підходів до препарування кореневих каналів.

За даними досліджень, які були проведені в Німеччині у 1997 році, було з'ясовано, що після вдало проведеної терапії у більш ніж 60 \% зубів були відмічені деструктивні процеси в періодонті [3]. Основною причиною цього було використання Аля того часу традиційної метоАики препарування і очистки кореневих каналів. При даному способі препарування не було можливості повністю видалити біоплівку з системи кореневих каналів [4].

Протягом останніх років постійно відбувається вдосконалення способів ендодонтичного лікування, яке пов'язане з появою нового інструментарію, технологій препарування кореневих каналів та їх обтурації. Якісне препарування кореневого каналу дає можливість тривимірної обтурації кореневого каналу, що в подальшому забезпечить успішність ендодонтичного лікування. Ще в 1974 році Shilder визначив наступні критерії формування кореневих каналів: досягнення оптимальної конусності; збереження анатомічної форми кореневого каналу; збереження апікального звуження кореневого каналу; обробка всіх поверхонь кореневого каналу [5].

Метою досліАження стало порівняння різних способів препарування кореневих каналів та їх обтурації.

Матеріали і методи. Аля лабораторних досліджень були вибрані найбільш розповсю-
Ажені у практичній роботі лікарів-стоматологів системи інструментів для препарування кореневих каналів: 1) ручні файли другої конусності фірми «MANI»; 2) ручні файли системи «Pro taper» (Dentsply); 3) машинні фрайли "Pro taper» (Dentsply); 4) машинні файли «Mtwo» (VDW).

Препарування кореневих каналів машинними фрайлами здійснювали за допомогою ендомотора «Safe-endo».

Кожним видом інструмента було проведено препарування кореневих каналів восьми екстрагованих зубів, з подальшою їх обтурацією силером на основі епоксидних смол "AH-plus» та гутаперчевими штифтами 2-ї, 4-ї та 6-ї конусностей.

3 кожного зуба було виготовлено по 1 поздовжньому шліфу зуба за нижченаведеною методикою. Всього було виготовлено 32 шліфи.

На видалених за медичними показаннями зубах фронтальної групи верхньої щелепи людей віком від 30 до 50 років здійснювали доступ до порожнини зуба, проводили очистку, формування кореневого каналу одним з вибраних способів та дезінфекцію кореневого каналу згідно з правилами ендодонтичного лікування. Проводили обтурацію кореневого каналу.

У першій групі препарування кореневого каналу проводили з допомогою ручних файлів методикою «Step back», обтурацію здійснювали силером «AH-plus» та гутаперчевими штифтами 2-ї конусності методом холодної латеральної конденсації штифта. В другій та третій групах препарували кореневий канал за допомогою ручних та машинних фрайів «Pro taper» методикою «Crown-down» - силером «AH-plus» і гутаперчевих штифтів 6-ї конусності. У четвертій групі зубів кореневі канали препарували за допомогою машинних файлів «МТwо» методикою «Crown-down». Обтурацію проводили силером «AH-plus» та гутаперчевими штифтами 4-ї конусності. Зразки розміщували в термостаті на 24 год для створення відповідного середовища, що відповідало сере- 
довищу порожнини рота за температурними параметрами. Через 24 год з кожного зразка зуба виготовляли по одному товстому поздовжньому шліфу. Одержували товсті шліфи шляхом поздовжнього направленого розпилу зубів у вертикальному напрямку відносно коронки зуба.

Проводили дослідження шліфів зубів за такими критеріями:

- додержання анатомічної форми кореневого каналу;

- наявність уступів у кореневому каналі;

- зберігання апікального звуження;

- якість обробки всіх поверхонь кореневого каналу;

- час препарування кореневого каналу;

- якість адгезії силеру і гутаперчевих штифтів до стінок кореневого каналу.

Результати досліджень та їх обговорення. При методиці стандартної обробки ручними файлами, за результатами дослідження товстих поздовжніх шліфів зубів, кореневі канали яких препарували 3 допомогою ручних файлів 2-ї конусності з подальшою обтурацією силером «AH-plus» та гутаперчевими штифтами методом холодної латеральної конденсації гутаперчі, спостерігають відхилення від анатомічної форми кореневого каналу. Кореневий канал не округлої форми. В ньому наявні уступи. Гутаперчові штифти 2-ї конусності нерівномірно прилягають до поверхні дентину кореневого каналу, між ними є невелика кількість силеру. Це в подальшому може призвести до порушення обтурації кореневого каналу та розвитку бактеріальної мікрофллори в ньому.

Отже, при роботі з ручним інструментом 2-ї конусності ми відмічали наступні недоліки: недостатньо швидке препарування; виникнення уступів, перфорацій; порушення анатомічної форми каналу; відсутність у ручних інструментах пам'яті форми; при довготривалій роботі з ними виникають професійні шкілливості (захворювання суглобів пальців кистей у зв'язку зі статичною фіксацією інструментів).

При застосуванні файлів системи «Pro taper» (Dentsply), за даними макроскопічного дослідження товстих шліфів зубів, кореневі канали яких препарували з допомогою ручних фрайлів «Pro taper» з подальшою обтура- цією силером «AH-plus» та гутаперчевими штифтами 6-ї конусності, кореневий канал має більш анатомічну форму порівняно 3 обробкою файлами 2-ї конусності. Кореневий канал наближається до округлої форми. В ньому немає уступів. Гутаперчевий штиф рівномірно обтурує кореневий канал на всьому протязі. Між штифтом і стінкою кореневого каналу є невелика кількість силеру, без наявності пустот.

Під час дослідження поздовжніх шліфів зубів, кореневі канали яких були відпрепаровані за допомогою машинних файлів «Рro taper» та обтуровані гутаперчевими штифтами 6-ї конусності з силером «AH-plus», визначають якісне препарування кореневого каналу зі збереженням анатомічної форми кореневого каналу, з поступовим його звуженням до верхівки кореня зуба. Визначають відсутність уступів у кореневому каналі. Штифт максимально щільно прилягає до дентину кореневого каналу на всьому його протязі. Спостерігають мінімальний шар силеру між штифтом та стінкою кореневого каналу. Це свідчить про максимально якісне препарування кореневого каналу та припасування штифта в ньому.

Під час дослідження поздовжніх шліфів зубів, кореневі канали яких були відпрепаровані за допомогою машинних файлів «Mtwo» (VDW), та обтуровані гутаперчевими штифтами 4-ї конусності з силером «АН-plus», свідчить про якісне препарування кореневого каналу, при якому канал зберігає свою анатомічну форму з мінімальним діаметром на верхівці кореня зуба. Спостерігають рівномірне препарування всіх поверхонь кореневого каналу, без наявності уступів. Штифт максимально щільно прилягає по всій довжині кореневого каналу з мінімальним шаром силеру між штифтом та стінкою кореневого каналу.

Висновки. У результаті дослідження з'ясовано, що для найефективнішого способу препарувавння кореневого каналу необхідно використовувати машинні фрайли «Mtwo» та «Pro taper». Вони забезпечують найбільш ефективне препарування кореневого каналу, дозволяючи зберігти при цьому найбільш анатомічну форму кореневого каналу. Це забезпечує якісну і довготривалу тривимірну обтурацію кореневого каналу з допомогою силеру «АН- 
plus» і гутаперчевих штифтів 4-ї та 6-ї конусностей. Також препарування кореневого каналу за допомогою машинних файлів потребує значно менше часу порівняно з препаруванням каналів із допомогою ручних файлів.

В якості альтернативного варіанту для препарування кореневого каналу можливо вико-

\section{Список літератури}

1. Боровский Е. В. Клиническая эндодонтия / Е. В. Боровский - М. : АО «Стоматология», 1999. $-176 \mathrm{c}$.

2. Боровский Е. В. Проблемы эндодонтического лечения / Е. В. Боровский // Клиническая стоматология. -1997 . - № 1. - С. 5-8.

3. Periapical staytus, quality of root canal fillings and estimated endodontic treatment needs in an urban German population / R. Weiger, S. Hitzler, G. Hermle, ристовувати ручні фрайли «Pro taper», які не потребують використання ендомотора.

У подальшому планується провести досліАження властивостей адгезивних систем різних хімічних груп та дати порівняльну характеристику стосовно твердих тканин зубів.

C. Lost // J. Endod. Dent Traumatol. - 2010. - № 13. - P. $79-84$.

4. Максимова О. П. Обзор новостей эндодонтии / О. П. Максимова, Н. М. Шеина // Клиническая стоматология. - 2009. - № 2. - С. 34-37.

5. Клиффорд Раддл. Система «ПроТейпер Универсальный». Любую свою мысль полезно обдумать снова / Раддл Клиффорд // Аент Арт. - 2007. - № 1. C. $49-53$. 